\section{Sindbis-Viren (SINV)}

W. Stöcker

Euroimmun Medizinische Labordiagnostika AG, Lübeck, Deutschland

Englischer Begriff Sindbis virus

Beschreibung des Erregers Familie: Togaviridae; Gattung: Alphavirus; Art: Sindbis-Virus; Subtypen: Ockelbo-Virus, Babanki-Virus; Plusstrang-RNA-Genom, behüllt.

Erkrankungen Verbreitung: Südafrika, Ägypten, Indien, Philippinen, Südostasien, Zentralasien, Russland, Australien, Nordeuropa.

Übertragung: Stechmücken (ornithophile Culex ssp., vor allem C. pipiens und C. torrentium, Aedes ssp. u. a.); verschiedene Vogelarten, darunter Zugvögel, dienen als Reservoir.

Klinik: Sindbis-Fieber, febrile Erkrankung mit Kopfschmerzen, Arthritis/Arthralgie, Exanthem, die etwa eine Woche andauert. Nur bei einem kleinen Teil der Patienten persistieren Gelenkbeschwerden.

Analytik Kultur: Virusanzucht.

Serologie: Nachweis spezifischer Antikörper (IgA, IgG, $\mathrm{IgM})$ im Serum durch indirekte Immunfluoreszenz ( $\triangleright \mathrm{Im}$ munfluoreszenz, indirekte), \ Enzyme-linked Immunosorbentassay, $>$ Neutralisationstest, Hämagglutinations-Hemmtest.

Probenmaterial Direktnachweis: Blut oder Blutbestandteile. Das Material sollte bis zur Weiterverarbeitung bei +4 bis $+8{ }^{\circ} \mathrm{C}$ aufbewahrt werden.
Serologie: Serum oder Plasma für den Nachweis der Antikörper sind bei $+4{ }^{\circ} \mathrm{C}$ bis zu 2 Wochen lang beständig, bei $-20{ }^{\circ} \mathrm{C}$ über Monate und Jahre hinweg. Zur Tiefkühlkonservierung des IgM kann man den Proben $80 \%$ gepuffertes Glyzerin beifügen.

Diagnostische Wertigkeit Ursache für Fieber mit Hautausschlag und Gelenkschmerzen können auch in Deutschland Sindbis-Viren sein. Der direkte Virusnachweis aus dem Blut ist während der ersten Krankheitstage möglich. Ab dem 8.-10. Tag nach Einsetzen der Symptome können spezifische Antikörper (IgM, IgG) nachgewiesen werden. Kreuzreaktionen mit Antikörpern gegen verwandte Viren sind möglich.

Differenzialdiagnose: virale Infektionen mit Gelenkbeteiligung (z. B. Dengue- und Chikungunya-Fieber), die in den Infektionsgebieten parallel auftreten, ggf. rheumatoide Arthritis, reaktive Arthritis.

Durch die Verordnung zur Anpassung der Meldepflichten nach dem Infektionsschutzgesetz an die epidemische Lage (IfSG-Meldepflicht-Anpassungsverordnung), die am 01.05.2016 in Kraft getreten ist, wurde die Meldepflicht für Labore nach $\S 7$ Abs. 1 Satz 1 Infektionsschutzgesetz (IfSG) auf den direkten oder indirekten Nachweis von ChikungunyaViren, Dengue-Viren, West-Nil-Fieberviren, Zika-Viren und sonstige Arboviren ausgedehnt, soweit der Nachweis eine akute Infektion anzeigt. Darüber hinaus können allgemeine nicht erreger- oder krankheitsspezifische Meldepflichten bestehen.

\section{Literatur}

Robert Koch-Institut, Berlin (2011) Steckbriefe seltener und importierter Infektionskrankheiten. Robert-Koch-Institut, Berlin 